\title{
Seasonal Variability of Waterlogging in Rangpur City Corporation Using GIS and Remote Sensing Techniques
}

\author{
Md. Naimur Rahman ${ }^{1}$, , Sajjad Hossain Shozib ${ }^{2}$ \\ ${ }^{1}$ Department of Geography and Environmental Science, Begum Rokeya University, Rangpur, \\ Park Mor, Modern, Rangpur, 5404, Bangladesh \\ ${ }^{2}$ Department of Environmental Engineering, Nanjing Forestry University, No.159 Longpan \\ Road, Nanjing, 210037, China
}

Received 28 November 2020/Revised 17 July 2021/Accepted 28 July 2021/Published 17 August 2021

\begin{abstract}
Waterlogging hazard is a significant environmental issue closely linked to land use for sustainable urbanization. NDWI is widely and effectively used in identifying and visualizing surface water distribution based on satellite imagery. Landsat 7 ETM+ and Landsat 8 OLI TIRS images of pre and post-monsoon $(2002,2019)$ have been used. The main objective of this study is to detect the seasonal variation of waterlogging in Rangpur City Corporation (RPCC) in 2002 and 2019. In the present study, we used an integrated procedure by using ArcGIS raster analysis. For pre and post-monsoon, almost 93\% accuracy was obtained from image analysis. Results show that in 2002 during the pre and post-monsoon period, waterlogged areas were about $159.58 \mathrm{~km}^{2}$ and $32.32 \mathrm{~km}^{2}$, respectively, wherein in 2019 , the changes in waterlogged areas are reversed than 2002. In 2019, during pre-monsoon, waterlogged area areas were $122.79 \mathrm{~km}^{2}$, and during post-monsoon, it increased to 127.05 $\mathrm{km}^{2}$. The research also depicts that the trend of the waterlogging situation largely depends on seasonal rainfall and a flawed drainage system.
\end{abstract}

Keywords : Seasonal variation; Waterlogging; Remote sensing; GIS; Rangpur City Corporation

\section{Introduction}

Waterlogging is considered a global concern, affecting 10-15 million hectares of wheat land annually and causes $20 \%$ - 50\% of total global yield loss. Loss of grain crops such as field peas, canola, barley, lentils, lupins, and chickpeas also get affected due to severe waterlogging worldwide. In the USA, $16 \%$ of soil, in Russia $10 \%$ of agricultural croplands and irrigated crop production in Bangladesh, India, China, and Pakistan get harmed just because of waterlogging (Bakker et al., 2007; Hossain \& Uddin, 2011; Romina et al., 2018; Solaiman et al., 2007; Yaduvanshi et al., 2012).

*Corresponding author.

Email address : naimurbrur@gmail.com (Md. Naimur Rahman) 
Water does not usually penetrate deep into the flat terrain, which increases the depth of groundwater since the subsurface land is filled. It is indeed a significant environmental hazard and is found worldwide (Bowonder et al., 1986), such as in Bangladesh (Minar et al., 2013), India (Choubey, 1998; Chowdary et al., 2008; Sahu, 2014), China (Quan et al., 2010), Pakistan (Qureshi et al., 2008) and others. Northern Bangladesh is exceptionally susceptible to environmental and quasi-natural potential hazards, such as waterlogging.

Siltation has become one of the key reasons for waterlogging that blocks the river water flow and causes congestion by the upstream drainage. In Southern Bangladesh, thousands of speople have lost their ability to make a proper living just because of waterlogging, particularly poor and landless farmers, share-holders, daily wage laborers, small traders, and others (Shaibur et al., 2019). Various previous studies have shown that GIS and RS techniques are useful for detecting and mapping waterlogged areas for different study areas (Guha et al., 2020; Hassan \& Mahmud-ul-islam, 2014; Khine et al., 2018; Mahmud et al., 2017; Sar et al., 2015).

Few authors mentioned adaptation strategies of waterlogging in some districts of Southern Bangladesh which have been described in the following literature (Islam et al., 2020; Shaibur et al., 2019). The causes and consequences of waterlogging have been shown in (Awal \& Islam, 2020) after analyzing using GIS and RS image analysis. Visualization of waterlogged areas was carried out using traditional methods, as well as the land survey. Still, these methods are time-consuming for regional studies and not even economically feasible. The combination of GIS with RS is an incredible alternative to the conventional method and assessment strategies in the degree of spatiotemporal differences in waterlogged regions (Chowdary et al., 2008).

A very few research papers have been found about the detection of waterlogging areas in different areas of Bangladesh, especially focusing on seasonal variation of waterlogging. Most importantly, found researches were focusing on some southern districts of Bangladesh. To date, no researches have been found which is focusing on any part of Northern Bangladesh. This paper is could be the pioneer of its category of novelty for evaluating the seasonal variation of waterlogging area detection for Northern Bangladesh using GIS and RS, especially for emerging cities like Rangpur City Corporation (RPCC).

In a new city like RPCC, waterlogging is one of the most severe problems because of improper drainage systems and narrow drains in the city area. This research is unique in a way that will help respective authorities and planners to realize the actual situation and develop a proper and planned drainage system to avoid waterlogging. NDWI application has significant importance in classifying waterlogged areas and determining waterlogged risk 
assessment and hazard mapping quickly, efficiently, and accurately. Therefore, the main objective of this study is to assess waterlogged areas in RPCC for both pre-monsoon and post-monsoon seasons in 2002 and 2019 where a reasonable attempt using GIS and RS has been undertaken.

\section{Methods}

Rangpur is one of the new city corporations in Bangladesh, with an area of $203 \mathrm{~km}^{2}$. Rangpur City Corporation is located on the banks of the river Ghaghat. This river serves as the natural drainage of the city. The human-made Shyamasundari Canal is the leading wastewater channel in the city. RPCC is located at the coordinate of $25^{\circ} 37^{\prime}$ to $25^{\circ} 54^{\prime}$ North latitude and $89^{\circ} 09^{\prime}$ to $89^{\circ} 21^{\prime}$ East latitude. Rangpur is classified as a high-temperature climatic zone because of its tropical wet and dry climatic phenomena (Islam \& Sarker, 2016). In the RPCC, permanent water sources such as rivers, lakes, ponds, and reservoirs cover 2235 ha, while seasonal water sources such as floods, swamps, and marshy areas cover 2032 ha. Furthermore, in the research area, planted trees, cultivated land, uncultivated soil, and builtup area each contributed 1016, 4267, 3251, and 7518 ha, respectively (Islam \& Sarker, 2016).

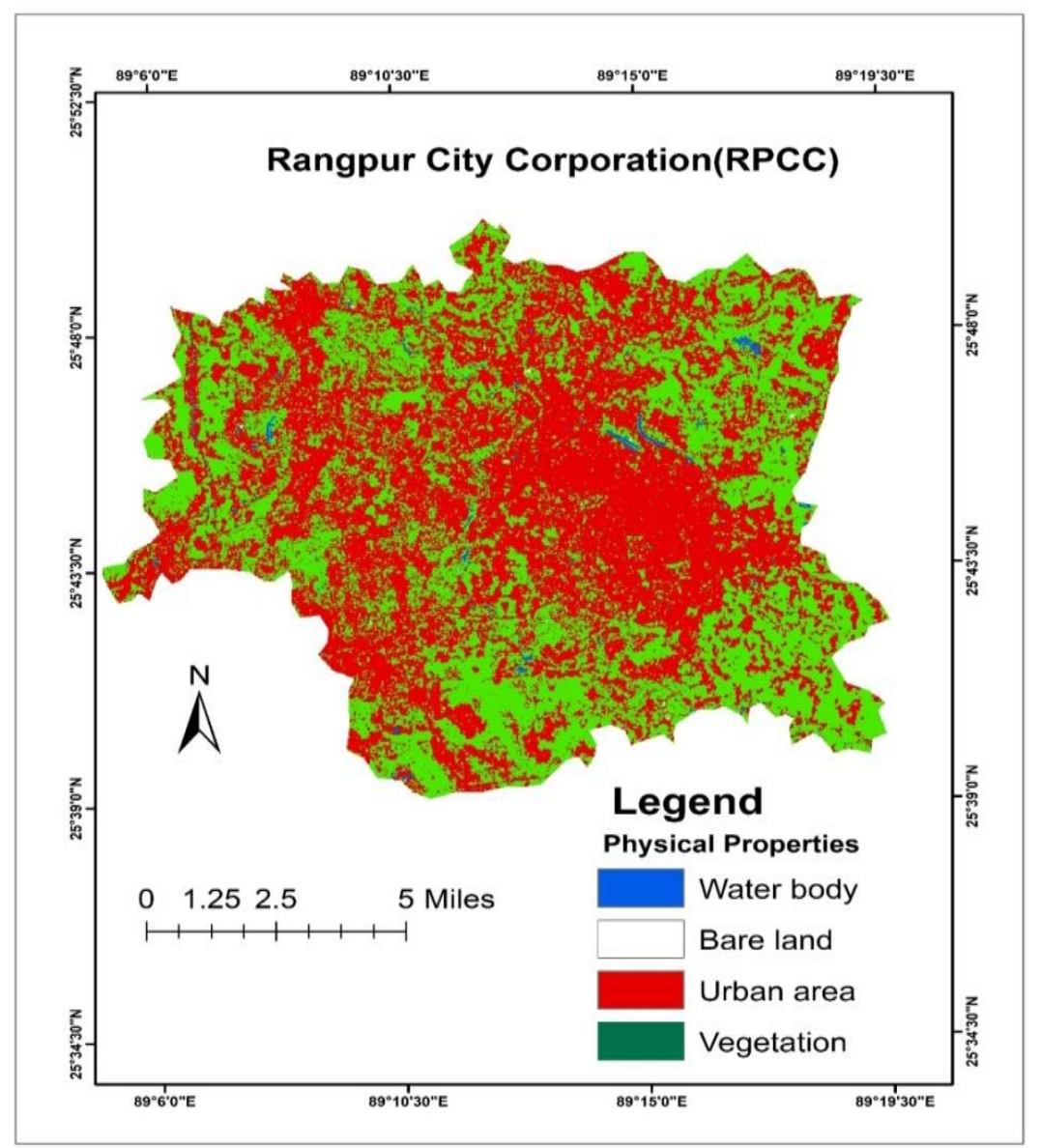

Figure 1. Study area with physical features (Rangpur City Corporation). Source: Adopted, modified and regenerated from Islam \& Sarker (2016) 
The research was carried out with satellite multitemporal Landsat 7 and Landsat8 images collected from the US Geological Survey (https:/earthexplorer.usgs.gov/). However, the path and row were selected 138 and 042 for image acquisition (Table 1) for 2002 and 2019. Depending on the April and November months of the valued year, the collected satellite images representing the pre-monsoon and post-monsoon seasons. The cloud-free environment for preparing the NDWI classification was ensured by obtained images (Chen \& Zhu, 2020). NDWI mapping, image classification, image processing, and change detection were performed through ArcMap10.6. To show a comparison of the average rainfall of Bangladesh and RPCC and more rainfall in April 2002 (Figure 4) data has been collected from Bangladesh Meteorological Department (2019) and Origin Pro 8.5 has been used to prepare the figure.

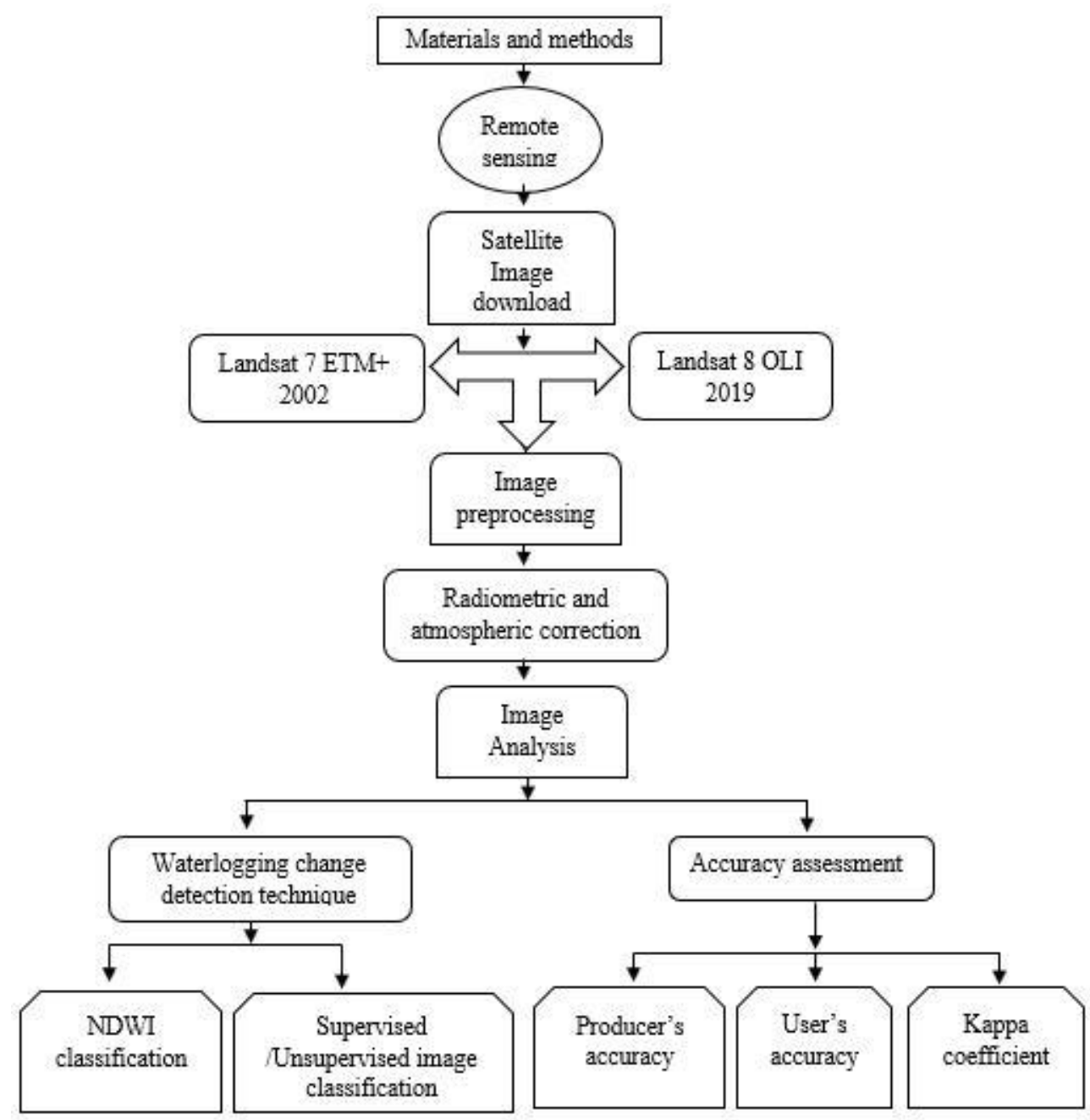

Figure 2. Methodological flow chart of waterlogging in RPCC 
Md. Naimur Rahman \& Sajjad Hossain Shozib / Geosfera Indonesia 6 (2), 2021, 143-156

Table 1. Landsat images

\begin{tabular}{ccccccc}
\hline Season & $\begin{array}{c}\text { Satellite } \\
\text { image }\end{array}$ & Date of acquisition & Sensor & $\begin{array}{c}\text { Path/ } \\
\text { row }\end{array}$ & $\begin{array}{c}\text { Spectral } \\
\text { resolution }\end{array}$ & Projection \\
\cline { 1 - 5 } Pre-monsoon & Landsat 7 & April 13, 2002 & ETM+ & $138 / 42$ & $30 \mathrm{~m}$ & UTM/WGS 84 \\
\cline { 2 - 5 } & Landsat 8 & April 20, 2019 & OLI TIRS & & & \\
Post-monsoon & Landsat 7 & November 7, 2002 & ETM+ & & & \\
\cline { 2 - 4 } & Landsat 8 & November 30, 2019 & OLI TIRS & & & UTM/WGS 84 \\
\hline
\end{tabular}

3.2 Classification and accuracy assessment of Normalize Difference Water Index (NDWI)

Normalize Difference Water Index(NDWI) was developed to detect water bodies' changes (McFeeters, 1996). In this study, NDWI is used (Mahmud et al., 2017) to analyze the seasonal waterlogged area in RPCC. The index can be seen in Eq.1 :

$\mathrm{NDWI}=p \mathrm{G}-p \mathrm{NIR} / p \mathrm{G}+p \mathrm{NIR}$

Where spectral reflectance is $p \mathrm{G}$ in the Green band, and spectral reflectance in NIR is indicating $p \mathrm{NIR}$.

The classified method could be more specified for Landsat 7 and Landsat 8 derivation method, can be seen in Eq.2 :

NDWI for Landsat 7:

Band 2 (Green) - Band 4 (NIR)/ Band 2 (Green) + Band 4 (NIR)

NDWI for Landsat 8 can be seen in Eq.3 :

Band 3 (Green) - Band 5 (NIR)/ Band 3 (Green) + Band 5 (NIR)

In these methods' positive high reflectance of NI Rand Green band is the indication of water bodies. Furthermore, positive and negative NDWI value demonstrates water and vegetation range from -1 to +1 value (Özelkan, 2020). Later, accuracy evaluation was applied to obtain the NDWI 's transparent pixel value. In addition, validation of the kappa coefficient, overall precision, and accuracy was carried out (Guha et al., 2020; Khine et al., 2018). Following the Google Earth photos, 350 points were randomly selected for the application of precision assessment. Study region means rainfall data were compared to country mean rainfall data to provide a clear overview between rainfall and waterlogging based on the month from 2002 to 2019. Furthermore, rainfall data were collected from Bangladesh Meteorological Department (2019). 


\section{Results and Discussion}

Table 2 illustrates the overall accuracy and Kappa coefficient. The demonstration also shows overall accuracy is higher than 89\% in each period of 2002 and 2019. In addition, we observed the kappa coefficient more than 0.83 in all images. A measurement of comparison was taken between sampling points (350 points) and google earth images for the same period to validate NDWI classifications. Besides, more than $90 \%$ validation values are counted for each period. Author opinions here as good accuracy was identified for Kappa statistics, overall accuracy, and validation.

Table 2. Accuracy assessment

\begin{tabular}{|c|c|c|c|c|c|c|}
\hline & \multicolumn{2}{|c|}{ User Accuracy } & \multicolumn{2}{|c|}{ Producer Accuracy } & \multirow[b]{2}{*}{$\begin{array}{c}\text { Classification } \\
\text { Accuracy }\end{array}$} & \multirow[b]{2}{*}{$\begin{array}{c}\text { Kappa } \\
\text { Statistics }\end{array}$} \\
\hline Period & $\begin{array}{c}\text { Vegetation } \\
\text { and Built- } \\
\text { Up Area }\end{array}$ & $\begin{array}{c}\text { Waterlogged } \\
\text { Area }\end{array}$ & $\begin{array}{c}\text { Vegetation } \\
\text { and Built- } \\
\text { Up Area }\end{array}$ & $\begin{array}{c}\text { Waterlogged } \\
\text { Area }\end{array}$ & & \\
\hline $\begin{array}{c}\text { Pre- } \\
\text { monsoon } \\
2002\end{array}$ & 85 & 100 & 75.84 & 100 & $91.00 \%$ & 0.899 \\
\hline $\begin{array}{c}\text { Post- } \\
\text { monsoon } \\
2002\end{array}$ & 96 & 89 & 90 & 100 & $89.57 \%$ & 0.835 \\
\hline $\begin{array}{c}\text { Pre- } \\
\text { monsoon } \\
2019\end{array}$ & 100 & 90 & 100 & 95 & $93.95 \%$ & 0.900 \\
\hline $\begin{array}{c}\text { Post- } \\
\text { monsoon } \\
2019\end{array}$ & 90 & 100 & 83.33 & 100 & $96.88 \%$ & 0.937 \\
\hline
\end{tabular}

In the years 2002 and 2019, waterlogged areas during pre-monsoon and post-monsoon periods in the study site were defined by GIS and RS techniques. The areas where waterlogged condition remains all-around year are perpetual waterlogged areas. Satellite images of April have been considered for pre-monsoon (most dry season) after excerpting areas under small lakes and ponds. In opposite, throughout the monsoon period, excessive rainfall causes seasonal inundation. Therefore, satellite images of water bodies for November have been considered (after the monsoon period) to detect the change of waterlogged areas (seasonal).

For the year 2002, Figure 3(a) shows that mostly the Northwestern part is waterlogged during pre-monsoon (early monsoon), but those areas are not permanently waterlogged. Because Figure 3(b) shows only a very few areas across RPCC are waterlogged, which is noticeable. However for the year 2019, in Figure 4(a) it is found that the North-west central part of RPCC is mostly waterlogged, not other parts, North-east central and Southcentral part of RPCC is less waterlogged during pre-monsoon. After the monsoon, Figure 
4(b) defines more areas than pre-monsoon area waterlogged, which means that estimated waterlogged areas increased.

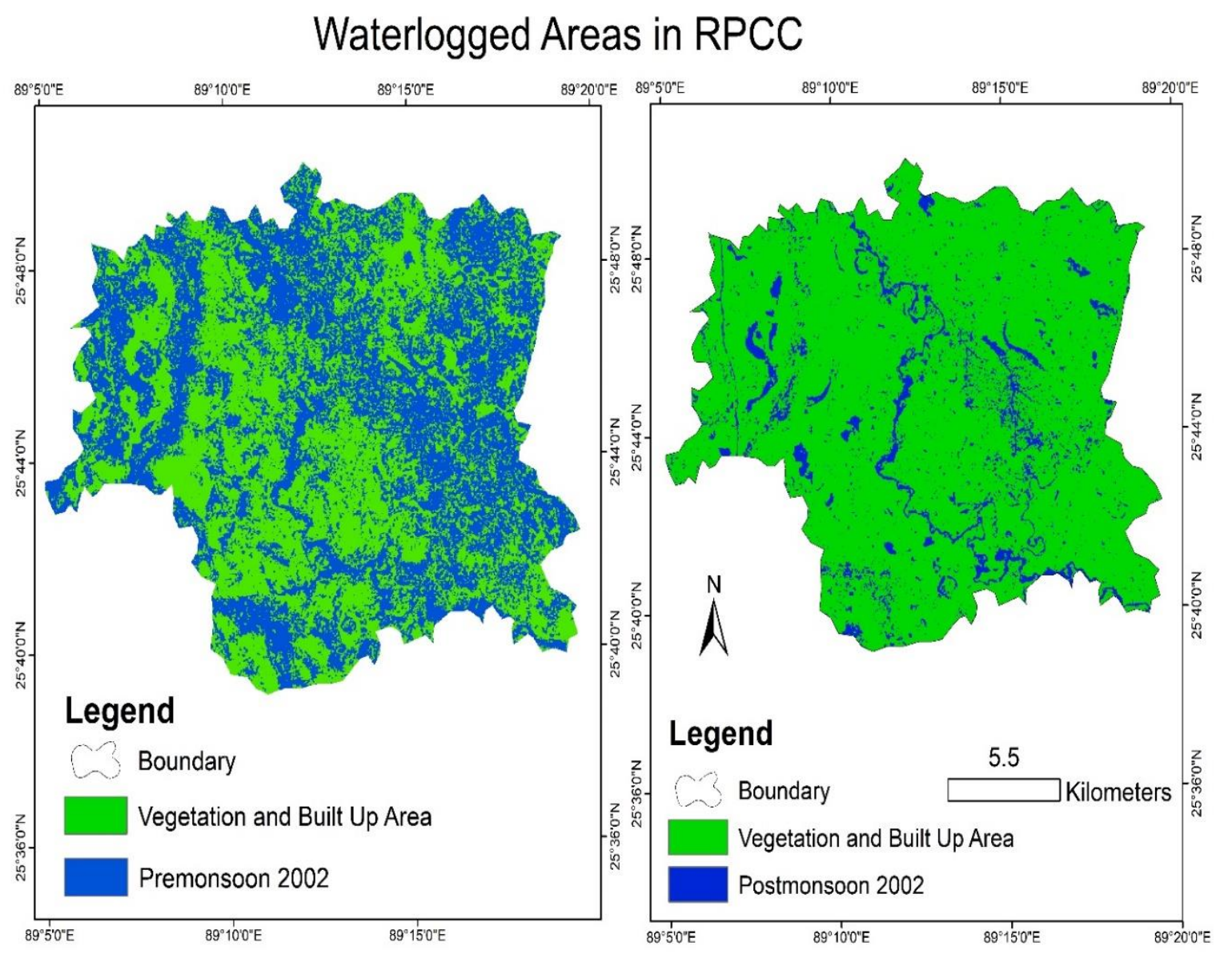

Figure 3. (a) Map showing waterlogged areas in RPCC during pre-monsoon in 2002 (left), (b) Map showing waterlogged areas in RPCC during post-monsoon in 2002 (right).

Monsoon in 2002 was early (Figure 5a), especially in April rainfall was third highest of 2002 (in mm). Therefore, during the pre-monsoon period in 2002 waterlogging areas in RPCC was more than comparatively in 2019 pre-monsoon (Figure 4a). 


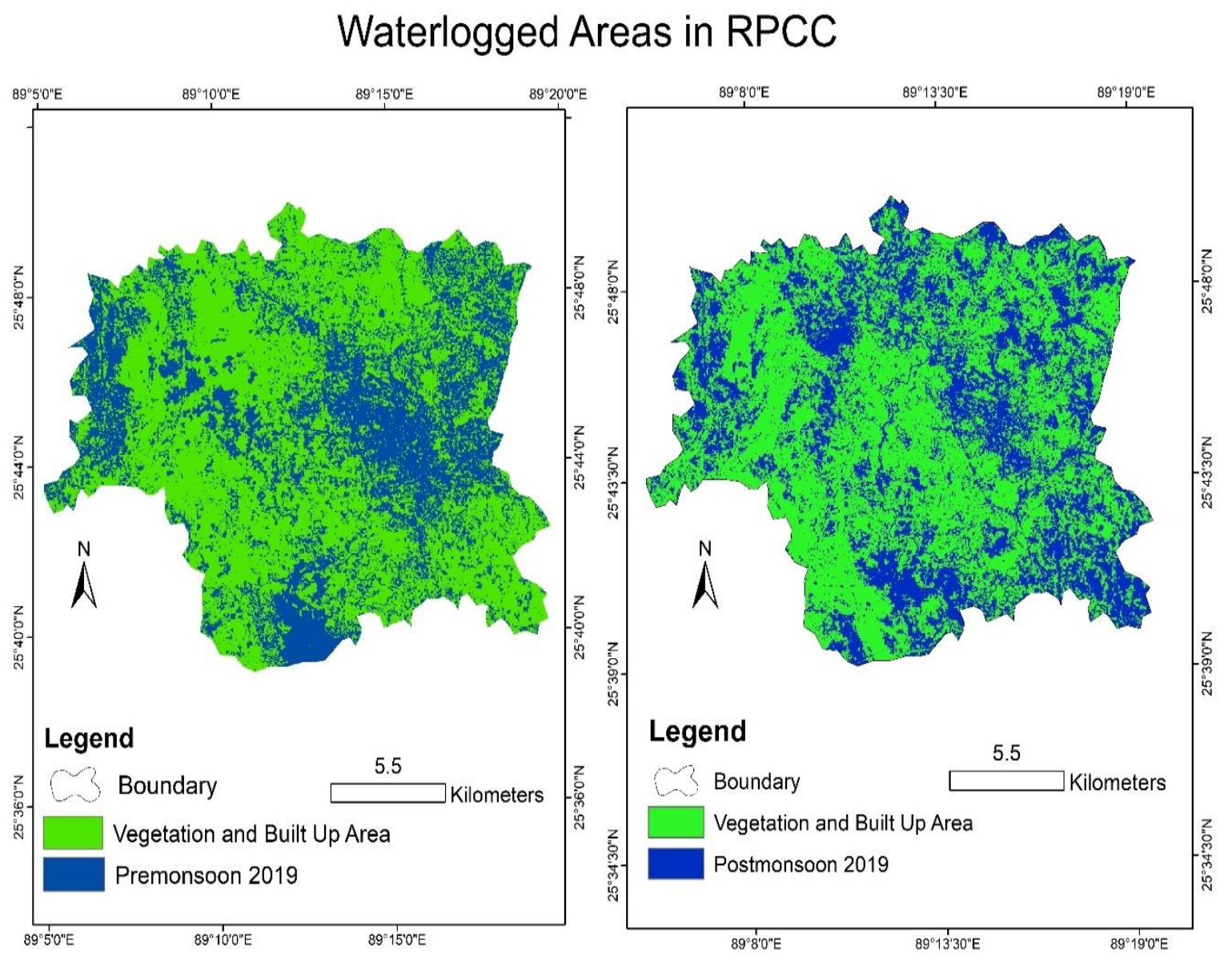

Figure 4. (a) Map showing waterlogged areas in RPCC during pre-monsoon in 2019 (left), (b) Map showing waterlogged areas in RPCC during post-monsoon in 2019 (right).

a)

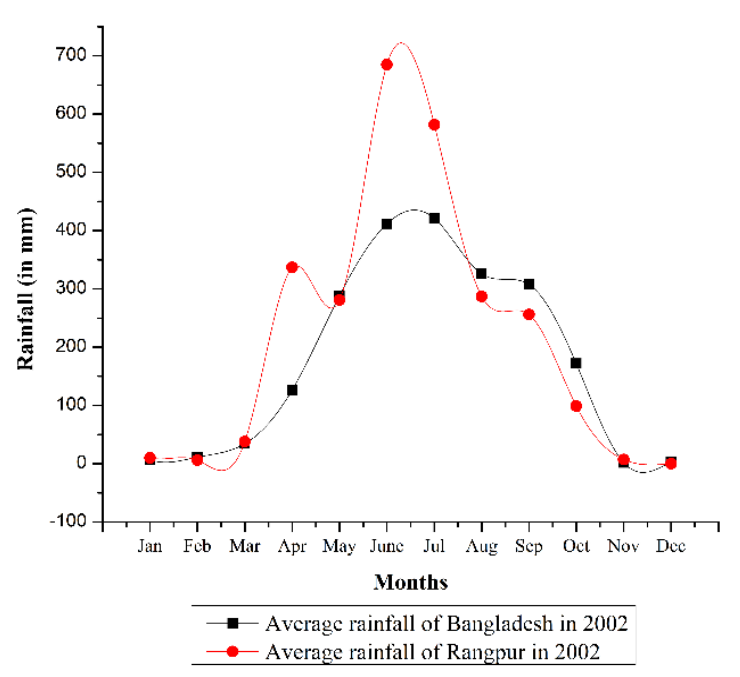

b)

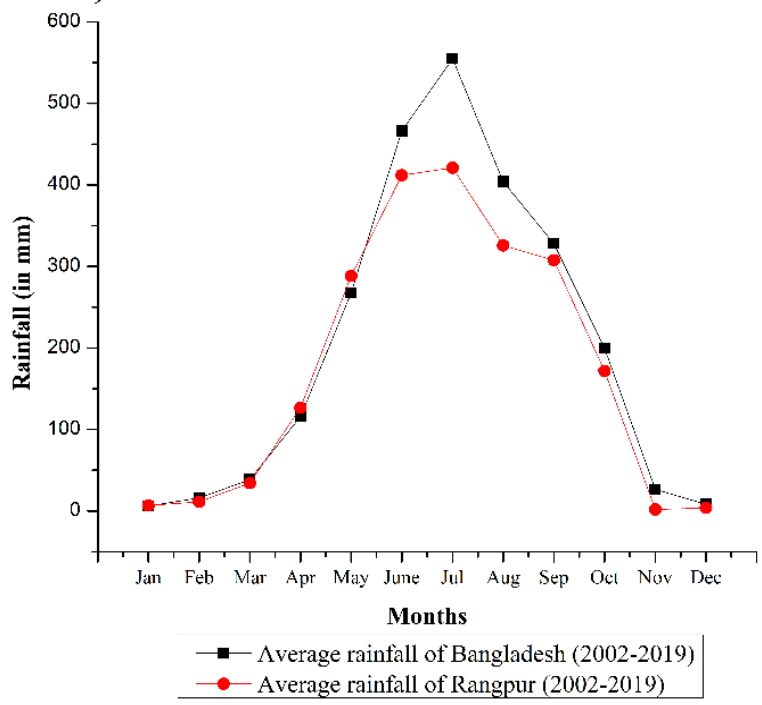

Figure 5. (a) Showing average rainfall of the year 2002. Where in April RPCC containing heavy average rainfall. (b) Comparison of average rainfall in Bangladesh and RPCC (Bangladesh Meteorological Department, 2019) 
Based on image analysis of the GIS environment, in RPCC, waterlogged areas changes have been considered (Table 3). It is found that in 2002 during the pre and postmonsoon period, waterlogged areas were about $159.58 \mathrm{~km} 2$ and $32.32 \mathrm{~km}^{2}$, respectively, which is $49.35 \%$ and $9.99 \%$ of the total area of RPCC. The result clearly shows decreased waterlogged area during post-monsoon than pre-monsoon $127.26 \mathrm{~km}^{2}$ by area $(39.36 \%)$. For the year 2019, the changes in waterlogged areas are reversed than in 2002. In 2019, during pre-monsoon, waterlogged area areas were $122.79 \mathrm{~km}^{2}(37.98 \%)$, and during post-monsoon, it increased to $127.05 \mathrm{~km}^{2}$, where the increase rate is $1.31 \%$.

Table 3. Waterlogged areas variation during pre-monsoon and post-monsoon periods in 2002 and 2019 in RPCC

\begin{tabular}{ccccccc}
\hline \multirow{2}{*}{ Year } & \multicolumn{2}{c}{ Pre-monsoon } & \multicolumn{2}{c}{ Post-monsoon } & \multicolumn{2}{c}{ Seasonal Variation } \\
\cline { 2 - 7 } & $\mathbf{k m}^{\mathbf{2}}$ & $\mathbf{\%}$ & $\mathbf{k m}^{\mathbf{2}}$ & $\mathbf{\%}$ & $\mathbf{k m}^{\mathbf{2}}$ & $\boldsymbol{\%}$ \\
\hline 2002 & 159.58 & 49.35 & 32.32 & 9.99 & 127.26 & 39.36 \\
2019 & 122.79 & 37.98 & 127.05 & 39.29 & 4.25 & 1.31 \\
\hline
\end{tabular}

Lack of a proper drainage system and heavy rainfall in the monsoon period causes waterlogging in RPCC. Figure 5 is showing, at some points, rainfall in the RPCC area is more than the average rainfall of Bangladesh. The study revealed high accuracy and validated data, which indicates transparent and essential observation. An analyzed value of more than $89 \%$ for overall accuracy, Kappa $>0.83$ and validation value $>90$ was observed where various investigations found kappa $>0.75$ is very good for measuring accuracy (Abbas et al., 2020; Foody, 2020; Morales-Barquero et al., 2019). Hazard and risk for waterlogging issue is a global problem that causes any country's impact economy (Sar et al., 2015).

In recent times it is reported that the study area is vulnerable to waterlogging due to heavy rainfall (The Daily Star, 2021). After analyzing Landsat images, the waterlogging problem is found in the current study area during both the pre and post-monsoon periods. Unpsredictable monsoon rainfall has been found from this study in both 2002 and 2019, wherein in the year 2002 there had been early monsoon, and in 2019 it was regular monsoon rainfall. However, waterlogging, floods, drought, and massive life losses could be determined through rainfall variability (Rahman \& Islam, 2019; Ullah et al., 2018).

The present study reveals the net change of waterlogged area for pre-monsoon is reduced from $49.35 \%$ to $37.98 \%$ where the post-monsoon inundated area is increased largely which is $9.99 \%$ to $39.29 \%$. Thus, meteorological observation in Figure 5 and Table 3 demonstrates an increase of waterlogged area in 2002 for the pre-monsoon season which corresponds to 2019. Hence, in the pre-monsoon season of 2002 high land, orographic 
rainfall, deep and low depressional behavior caused heavy rainfall as well as waterlogged area in the present area of study (Mannan \& Karmakar, 2008). Additionally, we detected heavy rainfall in the post-monsoon season for the year 2019 compared with 2002.

In recent times the geographical condition of the northern part of Bangladesh as it is situation closely Assam and Meghalaya hill and complex climate change pattern is the responsible factor for higher rainfall intensity during the post-monsoon season in RPCC (Montes et al., 2021; Islam et al., 2020). Furthermore, Islam et al. (2020) found an upward trend of rainfall, leading to an increased amount of waterlogged areas in the study area.

The present study also demonstrates the compared rainfall data of the study area and the entire country, which indicates the measurement of higher rainfall trend during monsoon season except for the pre-monsoon period of 2002, which indicates increased rainfall during the mentioned pre-monsoon period. However, seasonal flooding also causes waterlogged areas (Huda et al., 2019; Shaibur et al., 2019). When analyzing our data, we found that the study area is vulnerable to seasonal flooding (Talukdar et al., 2020). About flooding study area getting higher waterlogged areas, which varies seasonally. Besides, rising monsoon rainfall, upstream river flow by human intervention, unplanned aquaculture, and infrastructure can be explained as causes of waterlogging in the study area (Awal \& Islam, 2020; Ayyam et al., 2019; Islam et al., 2020).

\section{Conclusion}

Waterlogging hazard, risk, and vulnerability in RPCC combined with raster modeling by using integrated GIS and RS techniques can be useful for developing the drainage system of the city and sustainable management of water resources. The current study's outcome can be used by city planners, engineers, local people, and policymakers to identify and locally develop the most waterlogged areas. Thus an advanced drainage pattern could be developed based on the identified location of the findings. However, this research can be done using substantially more data for a long period to derive a trend in progress and seasonal fluctuations in waterlogging. Enormous statistical analysis can enhance the subtraction of NDWI for a more accurate depiction. The construction, upgrading of the necessary infrastructure of local weld, and excavation of silted Ghaghat river beside RPCC and Shyamasundari canal in RPCC can also be as useful to mitigate the waterlogging problem in the RPCC area.

\section{Conflict of interest}

The authors declare that there is no conflict of interest. 


\section{Acknowledgements}

Authors would like to acknowledge Ruhul Amin for his for his valuable comments on this study, Md. Morshadul Islam for his suggestions to improve language of this manuscript.

\section{References}

Abbas, Z., \& Jaber, H. S. (2020). Accuracy assessment of supervised classification methods for extraction land use maps using remote sensing and GIS techniques. In IOP Conference Series: Materials Science and Engineering (Vol. 745, No. 1, p. 012166). IOP Publishing.

Awal, M. A., \& Islam, A. T. (2020). Water logging in south-western coastal region of Bangladesh: causes and consequences and people's response. Asian Journal of Geographical Research, 9-28. https://doi.org/10.9734/ajgr/2020/v3i230102.

Ayyam, V., Palanivel, S., \& Chandrakasan, S. (2019). Land and Water Conservation: Dealing with Agriculture and Aquaculture Conflicts. Coastal Ecosystems of the TropicsAdaptive Management (pp. 391-406): Springer.http://dx.doi.org/10.1007/978-981-138926-9_17.

Bakker, D., Hamilton, G., Houlbrooke, D., Spann, C., \& Van Burgel, A. (2007). Productivity of crops grown on raised beds on duplex soils prone to waterlogging in Western Australia. Australian Journal of Experimental Agriculture, 47(11), 1368-1376. https://doi.org/10.1071/EA06273.

Bangladesh Meteorological Department (2019). Climate Data Portal. Retrieved from http://live3.bmd.gov.bd/.

Bowonder, B., Ramana, K., \& Rajagopal, R. (1986). Waterlogging in irrigation projects. Sadhana, 9(3), 177. https://doi.org/10.1007/BF02811964.

Chen, J., \& Zhu, W. (2020). Consistency evaluation of landsat-7 and landsat-8 for improved monitoring of colored dissolved organic matter in complex water. Geocarto International, 1-12. https://doi.org/10.1080/10106049.2020.1734872.

Choubey, V. (1998). Assessment of waterlogging in Sriram Sagar command area, India, by remote sensing. Water resources management, 12(5), 343-357. https://doi.org/10.1023/A:1008053705535.

Chowdary, V., Chandran, R. V., Neeti, N., Bothale, R., Srivastava, Y., Ingle, P., . . Sharma, J. (2008). Assessment of surface and sub-surface waterlogged areas in irrigation command areas of Bihar state using remote sensing and GIS. Agricultural water management, 95(7), 754-766. https://doi.org/10.1016/j.agwat.2008.02.009.

Foody, G. M. (2020). Explaining the unsuitability of the kappa coefficient in the assessment and comparison of the accuracy of thematic maps obtained by image classification. $\begin{array}{llll}\text { Remote Sensing of } & \text { Environment, } & 231630 .\end{array}$ https://doi.org/10.1016/j.rse.2019.111630.

Guha, S., Govil, H., \& Besoya, M. (2020). An investigation on seasonal variability between LST and NDWI in an urban environment using Landsat satellite data. Geomatics, Natural Hazards and Risk, 11(1), 1319-1345. https://doi.org/10.1080/19475705.2020.1789762. 
Hassan, M. S., \& Mahmud-Ul-Islam, S. (2014). Detection of waterlogging areas based on passive remote sensing data in Jessore District of Khulna Division, Bangladesh. International Journal of Scientific and Research Publications (IJSRP), 4 (12).

Hossain, M. A., \& Uddin, S. N. (2011). Mechanisms of Waterlogging Tolerance in Wheat: Morphological and Metabolic Adaptations Under Hypoxia Or Anoxia. Australian Journal of Crop Science, 5(9), 1094.

Huda, N., Terao, T., Murayama, S., \& Suenaga, Y. (2019). Detection of waterlogging floods in bengal mega-delta from people's perception underpinned by hydrometeorological dataset. Journal of Recent Advances in Marine Science and Technology, 13.

Islam, A., Rahman, M. S., Khatun, R., \& Hu, Z. (2020). Spatiotemporal trends in the frequency of daily rainfall in Bangladesh during 1975-2017. Theoretical and Applied Climatology, 141(3), 869-887. https://doi.org/10.1007/s00704-020-03244-x.

Islam, E., Khan, S. A., Khaleque, M. A., \& Ahammed, S. S. (2020). Waterlogging in the Southwest Coastal Areas of Bangladesh: Local Adaptation Techniques and Challenges. American Scientific Research Journal for Engineering, Technology, and Sciences (ASRJETS), 68(1), 112-119.

Islam, W., \& Sarker, S. C. (2016). Monitoring the changing pattern of land use in the Rangpur City corporation using remote sensing and GIS. Journal of Geographic Information System, 8(04), 537. https://doi.org/10.4236/jgis.2016.84045.

Khine, M. M., Maw, Y. Y., \& Win, K. M. M. (2018). Change analysis of indices (NDWI, NDVI, NDBI) for Mawlamyine City area using google earth engine. J. Myanmar Acad. Arts Sci., 16 (5).

Mahmud, M. I., Mia, A. J., Uddin, M. R., Rahman, M. M., \& Rahman, M. H. (2017). Assessment on seasonal variations in waterlogging using remote sensing and GIS techniques in Satkhira District in Bangladesh. Barisal University Journal, 4(1):67-80.

Mannan, M., \& Karmakar, S. (2008). Climatic feature of heavy rainfall activities in monsoon season and its socio-economic impact in Bangladesh. In Proceedings of SAARC Seminar on Application of Weather and Climate Forecasts in the Socio-economic Development and Disaster Mitigation (pp. 5-7).

McFeeters, S. K. (1996). The use of the Normalized Difference Water Index (NDWI) in the delineation of open water features. International Journal of Remote Sensing, 17(7), 1425-1432. https://doi.org/10.1080/01431169608948714.

Minar, M. H., Hossain, M. B., \& Shamsuddin, M. (2013). Climate change and coastal zone of Bangladesh: vulnerability, resilience and adaptability. Middle-East Journal of Scientific Research, 13(1), 114-120. DOI: 10.5829/idosi.mejsr.2013.13.1.64121. https://doi.org/10.15244/pjoes/110447.

Montes, C., Acharya, N., Hassan, S. M. Q., \& Krupnik, T. J. (2021). Intense precipitation events during the monsoon season in Bangladesh as captured by satellite-based products. Journal of Hydrometeorology. https://doi.org/10.1175/JHM-D-20-0287.1 
Morales-Barquero, L., Lyons, M. B., Phinn, S. R., \& Roelfsema, C. M. (2019). Trends in remote sensing accuracy assessment approaches in the context of natural resources. Remote Sensing, 11(19), 2305. https://doi.org/10.3390/rs11192305.

Özelkan, E. (2020). Water body detection analysis using NDWI indices derived from Landsat-8 OLI. Polish Journal of Environmental Studies, 29(2), 1759-1769. https://doi.org/10.15244/pjoes/110447.

Quan, R.-S., Liu, M., Lu, M., Zhang, L.-J., Wang, J.-J., \& Xu, S.-Y. (2010). Waterlogging risk assessment based on land use/cover change: a case study in Pudong New Area, Shanghai. Environmental Earth Sciences, 61(6), 1113-1121. https://doi.org/10.1007/s12665-009-0431-8.

Qureshi, A. S., McCornick, P. G., Qadir, M., \& Aslam, Z. (2008). Managing salinity and waterlogging in the Indus Basin of Pakistan. Agricultural Water Management, 95(1), 1-10. https://doi.org/10.1016/j.agwat.2007.09.014.

Rahman, M. S., \& Islam, A. R. M. T. (2019). Are precipitation concentration and intensity changing in Bangladesh overtimes? Analysis of the possible causes of changes in precipitation systems. Science of The Total Environment, 690, 370-387. https://doi.org/10.1016/j.scitotenv.2019.06.529.

Romina, P., Abeledo, L. G., \& Miralles, D. J. (2018). Physiological traits associated with reductions in grain number in wheat and barley under waterlogging. Plant and Soil, 429(1-2), 469-481. https://doi.org/10.1007/s11104-018-3708-4.

Sahu, A. S. (2014). A study on Moyna Basin water-logged areas (India) using remote sensing and GIS methods and their contemporary economic significance. Geography Journal, 2014, 1-9. https://doi.org/10.1155/2014/401324.

Sar, N., Chatterjee, S., \& Adhikari, M. D. (2015). Integrated remote sensing and GIS based spatial modelling through analytical hierarchy process (AHP) for water logging hazard, vulnerability and risk assessment in Keleghai river basin, India. Modeling Earth Systems and Environment, 1(4), 31. https://doi.org/10.1007/s40808-015-0039-9.

Shaibur, M. R., Shamim, A. H. M., Rizvi, M. M., Amara, U., \& Sarwar, S. (2019). Local Adaptation Strategies with Waterlogging Condition in Beel Kapalia Region, Jashore, Bangladesh. Environmental and Biological Research,1(1), 22-31. https://doi.org/10.1155/2014/401324.

Solaiman, Z., Colmer, T., Loss, S., Thomson, B., \& Siddique, K. (2007). Growth responses of cool-season grain legumes to transient waterlogging. Australian Journal of Agricultural Research, 58(5), 406-412. https://doi.org/10.1071/AR06330.

Talukdar, S., Ghose, B., Salam, R., Mahato, S., Pham, Q. B., Linh, N. T. T., . . Avand, M. (2020). Flood susceptibility modeling in Teesta River basin, Bangladesh using novel ensembles of bagging algorithms. Stochastic Environmental Research and Risk Assessment, 34(12), 2277-2300. https://doi.org/10.1007/s00477-020-01862-5.

The Daily Star (2021). Heavy Rain Disrupts Life in Dhaka. Retrieved from https://www.thedailystar.net/tags/heavy-rain. 
Islam, A. R. M. T., Rahman, M. S., Khatun, R., \& Hu, Z. (2020). Spatiotemporal trends in the frequency of daily rainfall in Bangladesh during 1975-2017. Theoretical and Applied Climatology, 141(3), 869-887. https://doi.org/10.1007/s00704-020-03244-x.

Ullah, S., You, Q., Ullah, W., \& Ali, A. (2018). Observed changes in precipitation in ChinaPakistan economic corridor during 1980-2016. Atmospheric Research, 210(C), 1-14. https://doi.org/10.1016/j.atmosres.2018.04.007.

Yaduvanshi, N., Setter, T., Sharma, S., Singh, K., \& Kulshreshtha, N. (2012). Influence of waterlogging on yield of wheat (Triticum aestivum), redox potentials, and concentrations of microelements in different soils in India and Australia. Soil Research, 50(6), 489-499. https://doi.org/10.1071/SR11266. 